\title{
CDISC SDTM Microbiology Test Code Terminology
}

National Cancer Institute

\section{Source}

National Cancer Institute. CDISC SDTM Microbiology Test Code Terminology. NCI

Thesaurus. Code C120527.

Terminology associated with the microbiology test code codelist of the Clinical Data

Interchange Standards Consortium (CDISC) Study Data Tabulation Model (SDT M). 